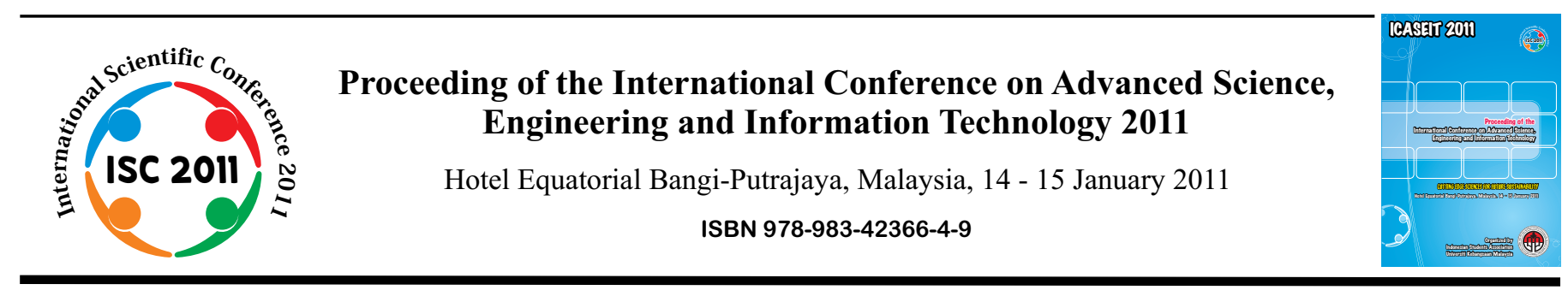

\title{
Toxicity of Nitrification Inhibitors on Dehydrogenase Activity in Soils
}

\author{
Ferisman Tindaon ${ }^{1)}$; Benckiser, $\mathrm{G}^{2)}$ and Johannes.C.G. Ottow ${ }^{2)}$ \\ 1). Agroecotechnology Department, Faculty of Agriculture, Nommensen University \\ Jl. Sutomo No. 4A Medan 20234 Indonesia \\ Tel. +62614522922 Fax: +62614571426 E-mail: Ferisman_Tindaon@yahoo.com \\ 2). Institute for Applied Microbiology, Justus Leibig University \\ Heinrich-Buff-Ring 26-32, 35392 Giessen, Germany \\ Tel. +49-641/99-37351,37352. Fax +49-641/99-37359
}

\begin{abstract}
The objective of this research was to determine the effects of nitrification inhibitors (NIs) such as 3,4dimethylpyrazolephosphate=DMPP, 4-Chlor-methylpyrazole phosphate=CIMPP and dicyandiamide, (DCD) which might be expected to inhibit microbial activity, on dehydrogenase activity (DRA) in three different soils in laboratory conditions. Dehydrogenase activity was assayed via reduction of 2-p-Iodophenyl-3-p-nitrophenyl-5-phenyltetrazoliumchloride (INT). The toxicity and dose response curve of three NIs were quantified under laboratory conditions using a loamy clay, a sandy loam and a sandy soil. The quantitative determination of DHA was carried out spectrophotometrically. In all experiments, the influence of 51000 times the base concentration was examined. To evaluate the rate of inhibition with the increasing NI concentrations, dose response curves were presented and no observable effect level =NOEL, as well as effective dose $\mathrm{ED}_{10}$ and $\mathrm{ED}{ }_{50}(10 \%$ and $50 \%$ inhibition) were calculated. The NOEL for common microbial activity such as DHA was about 30-70 times higher than base concentration in all investigated soils. CIMPP exhibited the strongest influence on the non target microbial processes in the three soils if it compare to DMPP and DCD. The NOEL, $\mathbf{E D}_{10}$ and $\mathbf{E D}_{50}$ values higher in clay than in loamy or sandy soil. The NIs were generally most effective in sandy soils. The three NIs considered at the present state of knowledge as environmentally safe in use.
\end{abstract}

Key words: toxicity, nitrification inhibitors ,dehydrogenase

\section{INTRODUCTION}

The assessment of microbial activity and the role of microorganisms in ecological systems, especially in response to environmental pollution, agrichemicals, demand reliable methods for estimating microbial biomass and activity in soils are known, e.g. measurement of ATP contents, substrate induced respiration, dehydrogenase and dimethyl suflidoxide reductase [1],[6],[7]. Soil quality changes resulting from environmental pedoturbation or management practices have been assessed through the use of soil enzyme. One such enzymes is the dehydrogenase whose activity is considered an indicator of oxidative metabolism in soils and thus of the microbiological. It represents the intercellular flux of electron to oxygen due to the activity of several intercellular enzymes catalyzing the transfer of hydrogen and electron from one compound to another [14]. Dehydrogenases are generally present in every upper layer of soils, and essential components of enzyme systems of microorganisms. Dehydrogenase activity can therefore be used as measure of microbial activity in soils [6], [8]. Side effects of agrochemicals use in environment can be measured by perceiving change of 
microbial population or with determining the microbial processes activity such as dehydrogenase activity.

Optimization of agricultural resources for improved and sustainable agriculture involves the use of nitrification inhibitors. Addition of nitrification inhibitors (NIs) to fertilizers have beneficial effect on reducing nitrate leaching and nitrous oxide emission and as a result increase plant growth (increase $\mathrm{N}$ use efficiency). The inhibitor should be bacteriostatic and not a bactericide which killing certain microorganism in soils like Nitrosobacter spp, Nitrosococcus sp. Finally, this NI have no negative influence on common microbial activity which is non target in soils [11], [21].

More than 300 type of nitrification inhibitors recently have been well recognized and used in agriculture. Some of these NIs consisted of N-heterocyclic compounds, acetylene derivates, sulphates and also various pesticides and herbicides [10], [16]. The DMPP and CIMPP were developed and produced by Bayerische Acetylen of Soda Fabrik (BASF) Ltd Company, Limburgerhof Germany. Dicyandiamid (DCD) produced by SKW Trotsberg Ag. Trotsberg Germany. Upon these NIs is an ammonium stabilizator in the field and also decrease the accumulation and nitrate leaching, reduce nitrous oxide emissions [2], [3], [7], [9], [ 26], improve $\mathrm{N}$ supply for crop, raise the yields of various crops [13], [17], [27]. Though some researchers have reported the effectiveness of these substances as inhibitors but ecologically, it requires being determined its influence to microbial activity in soils and their residue effects in the environment.

Therefore the toxicity of the nitrification inhibitors to main microbial processes should be assessed. This standard methods have been recognized to know the side effects of chemicals use to environment which can be checked either in laboratory and also in the field [24].

\section{Soil Samples}

\section{MATERIALS AND METHODS}

In this study three different types of soil samples were used which varied in their chemical and physical properties (Table 1.).

TABLE I

GENERAL PROPERTIES OF EXPERIMENT SOILS

\begin{tabular}{|c|c|c|c|}
\hline \multirow{2}{*}{ Parameters } & \multicolumn{3}{|c|}{ Type of Soil } \\
\cline { 2 - 4 } & $\begin{array}{c}\text { Loamy } \\
\text { clay }\end{array}$ & Loam & Loamy sand \\
\hline $\mathrm{C}_{\text {-total }}(\%)$ & 1,35 & 1,30 & 0,70 \\
\hline $\mathrm{C}_{\mathrm{H} 2 \mathrm{O}}(\%)$ & 0,40 & 0,55 & 0,27 \\
\hline $\mathrm{N}_{\text {total }}(\%)$ & 0,15 & 0,15 & 0,08 \\
\hline $\mathrm{C} / \mathrm{N}$ & 10 & 9 & 9 \\
\hline $\mathrm{pH}_{\mathrm{H} 2 \mathrm{O}}$ & 6,30 & 7,00 & 7,00 \\
$\mathrm{pH}_{\mathrm{KCl}}$ & 6,00 & 5,50 & 6,40 \\
\hline Fraction $(\%)$ & & & \\
Clay & 51 & 24 & 6 \\
Loam & 41 & 46 & 19 \\
Sand & 8 & 30 & 75 \\
& & & \\
\hline
\end{tabular}

\section{Nitrification Inhibitors}

Three kind of NIs were applied: 3,4dimethylpyrazolephosphate=DMPP and 4-Chlormethylpyrazole phosphate=ClMPP (Purity 99,9\% and 99,7 \%) were produced by BASF AG, Ludwigshafen Germany. Dicyandiamid ( $\mathrm{DCD}=$ Purity $96 \%$ ) produced by
SKW Trotsberg Ag. Trotsberg Germany. These three NIs were applied at recommendation rates 0,36 $\mu \mathrm{g}$ DMPP, $0,25 \mu \mathrm{g}$ CIMPP and $10 \mu \mathrm{g}$ DCD g ${ }^{-1}$ dry soil. These rates were equal to that incorporated in $\mathrm{N}$-fertilizer for $90 \mathrm{~kg} \mathrm{~N}$ per Ha. In addition to this recommendation rate, higher NIs concentrations were also included in the experimental set up so as to predict its likely side effects on microbial non target processes in the events its excessive use. The application rates used in the present study included 1, 5, $10,25,50,100,250,500$ and 1000 times of base concentrations.

\section{Dehydrogenase Activity Assays}

Dehydrogenase activity (DHA) as an index of microbial activity was determined using 2-p-iodophenyl-3p-nitrophenyl-5-phenyltetrazoliumchloride (INT) as substrate and by spectrophotomectric quantification of produced formazan, [16],[21]. The method relies on the reduction of INT by microorganisms to Iodonitrotetrazolium-Formazan (INF). The concentration of INF was measured on a spectrophotometer (Fa. Zeiss PM2-DL) at $436 \mathrm{~nm}$ using methanol as blank.

\section{Samples Preparations:}

$2.5 \mathrm{~g}$ of air-dried soil were weighed in $50 \mathrm{ml}$ test-tubes (five parallels) and with $2.5 \mathrm{ml}$ of a Iodonitrotetrazoliumchlorid (INT) buffer solution were added. To produce the INT-buffer solution were $12.11 \mathrm{~g}$ Tris (hydroxymethyl) amino-methane (Merck) in $600 \mathrm{ml}$ distilled water and filled up to 1 litre. Then, the $\mathrm{pH}$ was adjusted with a few drops of hydrochloric acid (1 mol) up to $\mathrm{pH}$ 7.6. INT in Tris buffer (Fluka Chemie AG, Buchs, Switzerland) was dissolved with an ultrasonic probe (Sonorex, RK 100 H, Bandelin Electronic, Berlin). Due to the different sorption capacity of the three test soils, the INT concentration according to the guidelines of [19] was set differently. The optimal concentration for the sandy soil was INT $9 \mathrm{mg} \mathrm{ml}^{-1} \mathrm{mg}$, for loamy soil INT $15 \mathrm{mg} \mathrm{ml}^{-1}$ and for the clay soil INT $18 \mathrm{ml}^{-1}$ buffer. The soils mixed with the corresponding INT-containing buffer solutions (Whirlmix) for $4 \mathrm{~h}$ at $25^{\circ} \mathrm{C}$ incubated (incubator). The violet- Iodonitrotetrazolium formazan(INF) as reduction product then extracted after mixed or shake for $1 \mathrm{~h}$ with 10 $\mathrm{ml}$ of tetrahydrofuran. The extracts kept in the semi-dark room for $2 \mathrm{~h}$ and homogenized by hand and filtered. Subsequently, the supernatant INF were measured in the photometer (Zeiss PM2 DL) at the absorbance at $436 \mathrm{~nm}$. The DHA was taken from a calibration curve with INF first and expressed in $\mu \mathrm{g} \mathrm{g}^{-1} \mathrm{~h}^{-1}$ dry soil. The results presented as the averages from at least four parallels.

\section{Statistical Analysis}

Non linear regression analysis to drive ecotoxocological value were conducted on untransformed data from assays based on the concentration-response relationship for quantitative endpoint data, using regression model described in [20]. Analysis of variance (ANOVA) and Fisher's least significant difference pair wise comparison tests were applied to litter mass loss and enzymatic activity data for NOEL, $\mathrm{ED}_{10}$ and $\mathrm{ED}_{50}$ determinations. Differences were considered to be significant at a probability level of $\mathrm{P}<0.05$. Statistical analyses were performed using SigmaPlot and SigmaStat Software. 
Figure 1 show that the effect of increasing concentrations of the NIs on dehydrogenase activity in clayey soil occurs if DMPP and CIMPP used in 50 times of the recommended dose. These were equivalent to $18 \mu \mathrm{g}$ DMPP, $6.3 \mu \mathrm{g}$ ClMPP per gram of dry soil. While the new DCD visible effects occurred if used as many as $250 \mu \mathrm{g}$ DCD per gram of soil. Based on absolute doses, it can be concluded that the NOEL values of three NIs for dehydrogenase activity is $18 \mu \mathrm{g}$ DMPP, $6.3 \mu \mathrm{g}$ ClMPP and $250 \mu \mathrm{g}$ DCD per gram of soil. Therefore the application of these inhibitors in corporate in $\mathrm{N}$ - fertilizer on recommended dose which equivalent to $90 \mathrm{~kg} \mathrm{~N}$ per hectare did not affect dehydrogenase activity in clayey soils.
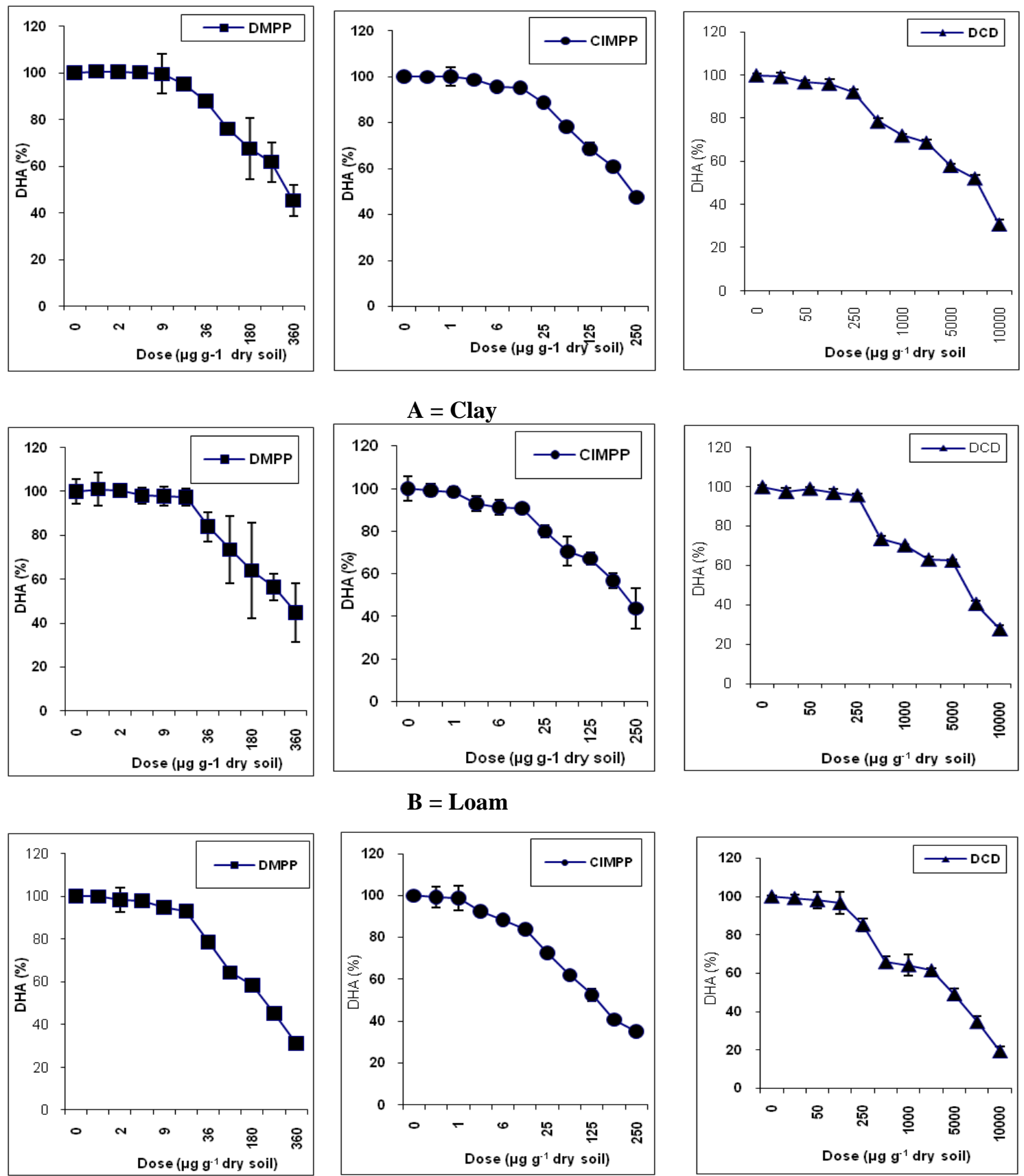

\section{$\mathrm{C}=$ Sand}

Fig. 1. The effect of increasing the concentration of NI DMPP, CIMPP and DCD on dehydrogenase activity (\% control) in clayey soil (A), loamy soil (B) and sandy soil (C). Recommendation dosage were $0.36 \mu \mathrm{g}$ DMPP; $0.25 \mu \mathrm{g}$ DCD;ClMPP and $10 \mu \mathrm{g} \mathrm{DCD} \mathrm{g}^{-1}$ dry soil

A comparison with clayey soil (Fig. 1A) shows that DMPP, CIMPP and DCD inhibited the DHA at 25 times of base concentrations in loamy soil (Fig. 1B). The NOEL values in clay are $6 \mu \mathrm{g}$ CIMPP, $9 \mu \mathrm{g}$ DMPP and
$250 \mu \mathrm{g}$ DCD $\mathrm{g}^{-1}$ dry soil. It appears that the inhibitory effects of individual NI on general non target microbial activities are significantly larger in clayey soil (Fig.1A. and $1 \mathrm{~B}$ ). 
Even in sandy soil (Fig.1C) the DHA was less affected. In contrast to the clay and loamy soil placed in the sandy soil and the DMPP-induced inhibitory effects of DHA CIMPP already at 5 times the concentration of a base (Fig. 1C). NOEL values for DHA in clay soils is $3.6 \mu \mathrm{g}$ DMPP; $2.5 \mu \mathrm{g}$ CIMPP and $100 \mu \mathrm{g}$ DCD $\mu \mathrm{g}$ per gram of dry soil. It turned out that in sandy soil inhibitory effect occurred faster and at lower concentrations (Fig.1C). Ecotoxicity of CIMPP was greater than DMPP and DCD, and more effective in inhibiting DHA in sandy soil than loamy and clayey soil. Only at the 750-fold in recommended concentration DMPP or CIMPP should inhibited DHA up to about 50\% (ED50). The ED50-values for CIMPP at $160 \mu \mathrm{g}$, approximately $250 \mu \mathrm{g}$ of DMPP or for $\mathrm{DCD}$ at $5000 \mu \mathrm{g} \mathrm{g}^{-1}$ dry soil. A comparison with the clay soil (Fig. 1C and Table 2) and the silty clay (Fig. 1B) occurs that the side effects of NI in the sandy soil are not only intense, but also started clearly earlier (Fig. 1C).

The comparison also shows that the DHA of the various soils of DMPP and ClMPP is inhibited significantly more than DCD. The NOEL values for DMPP and CIMPP are significantly smaller than the corresponding values for DCD (CIMPP $<$ DMPP $<<$ DCD). The side effects of the three terms of NI DHA decrease in the order sand $>$ silt $>$ clay (Table 2).

Ecotoxicity of Substances and Dose Response
Relationships
Mathematical model for ecotoxicological test on the NOEL, ED10 and ED50 for the three NIs data can be studied constructively by using Sigma plot and Sigma stat. So that approach method showed the threshold of ecotoxocological parameters the substances were determinable (Table. 2). If using ordinary linear equation regression hence determination assess the NOEL from measurement data was not at all enabled. For example, a semilogaritmic dose response relationship between three NIs (DMPP, CIMPP, DCD) and dehydrogenase activity in clay soil presented in Figure 2. By using the equation for dose response curve [16], [20]. in Sigma Plot Program where as:

$$
Y=a /\left(1+\exp \left(-\left(X_{t}-X_{0}\right) / b\right)\right)
$$

it is posible to calculate critical value for NOEL, $\mathrm{ED}_{10}$ and $\mathrm{ED}_{50} . \mathrm{Y}=$ response, a for the maximum response, Xo and $\mathrm{Xt}=\log$ dose of used NIs according to time and $\mathrm{b}$ for $\mathrm{a}$ constant of the NI-influence.

There is no clear toxicity difference between each nitrification inhibitors, due to NOEL, $\mathrm{ED}_{10}$ and $\mathrm{ED}_{50^{-}}$ values. Based on response average values, it can be concluded that CIMPP has more potential side effect on the activities of non target microbes in the soil. This is apparently caused by the effect of halogen element, like chlor, that effectively affects the microbial activity in the soil [7]. Based on the NOEL value, the use of these inhibitors on the dose of 100 times of the recommended dose does not negatively affect the soil environment. All three inhibitors affect non target microbial activities in sandy soils more effectively than in loamy or clayey soils. This is due to the influence of soil clay fraction content that plays a role in adsorption mechanism of inhibitors on the clay surface [3].

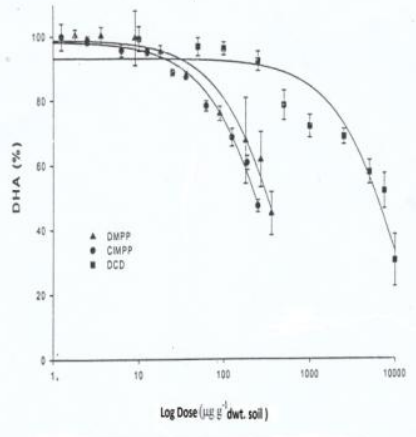

Fig. 2. The effect of increasing the concentration of NI DMPP, CIMPP and DCD on dehyrogenase activity (\% control) in clayey soil (semilogaritmic, the dose in the $\log$ ). Dosage recommendations, were $0.36 \mu \mathrm{g}$ DMPP; $0.25 \mu \mathrm{g}$ CIMPP and $10 \mu \mathrm{g}$ DCD per gram dry soil.

Environmental risk threshold value was studied based on [20], that for laboratory trials the average NOEL-value was divided by 10 and for field trials the average NOEL value was divided by 100 (Table 2). The derived from $\mathrm{ED}_{10}$ and $\mathrm{ED}_{50}$ values Toxicity index $\left(\mathrm{Ti}=\right.$ ratio of $\mathrm{ED}_{50}$ and $\mathrm{ED}_{10}$ value) describes the intensity decrease with the microbial activities in toxic doses. It turned out that the environmental risk threshold value is still far above the value of 1-50 times $\mathrm{N}$ fertilizer recommended dose (inhibitor incorporated with $\mathrm{N}$ fertilizer). The current recommended rate for DCD is $10 \mathrm{~kg}$ DCD ha ${ }^{-1}$ per application [7] and DMPP was applied as the commercial product Urea with ENTECTM $(1.84 \mathrm{~kg}$ DMPP active ingredient/t urea or $0.71 \mu \mathrm{g} \mathrm{DMPP} / \mathrm{g}$ soil [4]; [5]. Later, ClMPP was not recommended to be used in agriculture practices.

\section{CONCLUSIONS}

Based on the results, conclusion can be summarizes as follows:

- Based on dose response-curves for DHA recorded suggest that DMPP, CIMPP and DCD may affect dehydrogenase activity in soils only at high concentrations.

- The effects of the NIs on DHA were observed if rates about 70-90 times the base concentrations, corresponding to $17 \mu \mathrm{g}$ ClMPP, 30 $\mathrm{g}$ DMPP and 900 $\mu \mathrm{g} \mathrm{DCD} \mathrm{g}^{-1}$ dry soil were applied (NOEL-value).

- Generally, ClMPP exhibited the strongest influence on non target microbial processes in the three soils compared to DMPP and DCD.

- The NOEL, $\mathrm{ED}_{10}$ and $\mathrm{ED}_{50}$-values much higher in clay than in loamy sand or sandy soil. The NIs was generally the most effective in sandy soils.

It should be recommended, that there are no negative effects of CIMPP, DMPP and DCD on dehydrogenase activity in soils at base concentration. DMPP and CIMPP and DCD should be considered as environmentally compatible and safe. 
TABLE II

NOEL ASSESSMENT OF ED E $_{10}$ and ED ${ }_{50}$ FOR THE THREE NITRIFICATION INHIBITORS IN RELATION WITH DEHYDROGENASE ACTIVITY IN CLAY, LOAM AND SANDY SOIL BASED ON EQUATIONS OF MATHEMATICAL MODELS.

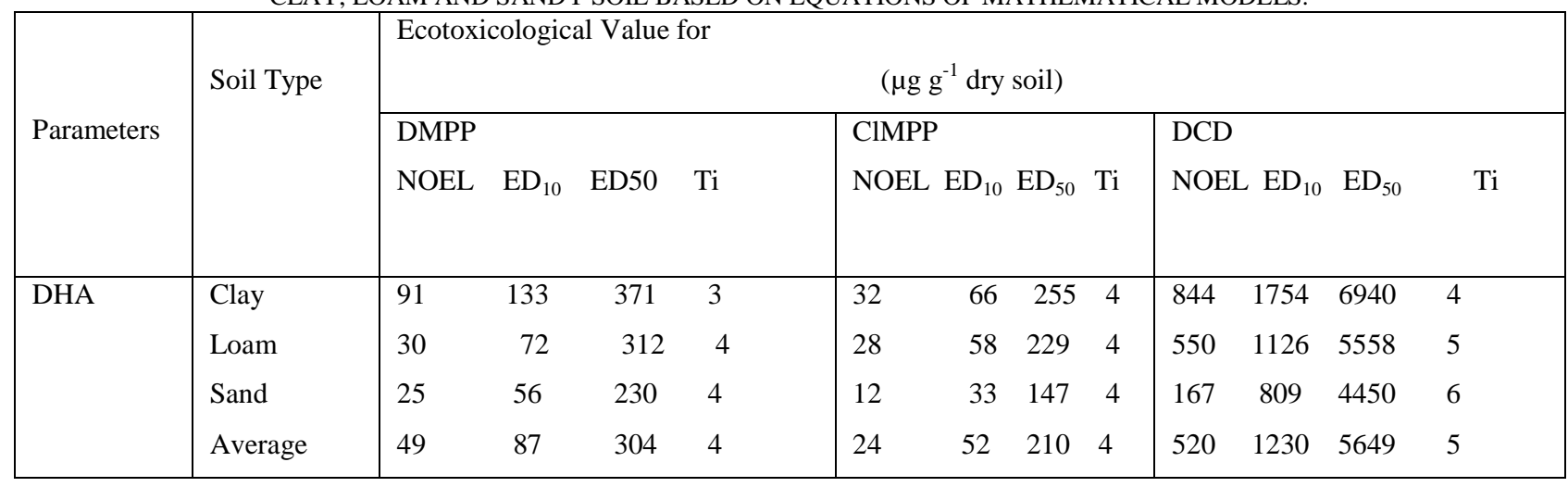

\section{ACKNOWLEDGMENT}

We thanks to PD Dr. G. Benckiser, Prof. Dr. J.C.G. Ottow in Institut for Applied Microbiology, University of

\section{REFERENCES}

[1] Alef, K.1995. Dehydrogenase activity. In: Alef and Nanniperi, $P$ (eds) Methods in Applied soil microbiology and biochemistry. Acad. Press. London pp. 228-231

[2] Azam, F,. Benckiser, G, Muller, C and J.C.G. Ottow.2001: Release, movement and recovery of 3-4 dimethylpyrazole phosphate (DMPP), ammonium and nitrate from stabilized fertilizer granules in a silty clay soil under laboratory conditions. Biol. Fertil. Soils 34: 118-125

[3] Barth, G, Tucher, S von and U. Schmidhalter. 2001. Influence of soil parameter on the effects of 3-4 dimethylpyrazole phosphate (DMPP) as nitrification inhibitor. Biol. Fertil, Soil. 34 : 98-102

[4] Barth G (2006) Influence of soil properties on the effect of 3,4 - dimethylpyrazole - phosphate as nitrification inhibitor. Technischen Universität München.

[5] -------- 2008. Effectiveness of 3,4-Dimethylpyrazole Phosphate as Nitriflcation Inhibitor in Soil as Influenced by Inhibitor Concentration, Application Form, and Soil Matric Potential. Pedosphere:18: 378385

[6] Debus, R and K. Hund. 1998. Development of analytical methods for assessment of ecotoxicological relevant soil contamination: Part B - Ecotoxicological Analysis in Soil and Soil Extracts. Chemosp: Vol 35 : pp . $239-261$

[7] Di HJ, Cameron KC (2005) Reducing environmental impacts of agriculture by using a fine particle suspension nitrification inhibitor to decrease nitrate leaching from grazed pastures. Agric Ecosyst Environ 109: 202-212.

[8] Engelen, B; Meinken, K; von Winzingerode, F; Heuer, H, Malkomes.H.P and H. Backhaus. 1998.: Monitoring impact of pesticide treatment on bacterial soil communities by metabolic and genetic fingerprint in addition to conventional testing procedures. Appl. And Envir. Microbiology : 64, pp: 2814-2821.

[9] Linzmeier, W., Guster, R and U. Schmidhalter.2001. Nitrous oxide emission from soil and from a nitrogen 15-labelled fertilizer with new nitrification inhibitor 34 dimethylpyrazole phosphate (DMPP). Biol. Fertil. Soils: 34: 103 - 108
Giessen, Germany for helping and supporting the experiment works. Special thanks we express to DAAD (Deutscher Akademischer Austauschdienst) in Bonn for providing the financial support.

[10] Mc Carty, G.W. 1999. Modes of action nitrification inhibitors. Biol Fertil, Soils. 29: 1-9.

[11] Mc Taggart, I.;Clayton, H.;Parker, J.; Swan, L. and K.A.Smith. 1997. Nitrous oxide emissions from grassland and spring barley, following $\mathrm{N}$ fertilizer application with and without nitrification inhibitors. Biol. Fertil. Soils:25:261-268

[12] Mosier, A.R (1998). Soil processes and global exchange. Biol. Fertil. Soils. 27: 221-229

[13] Pasda, G.K, Hanhdel, G and W. Zerulla. 2001. Effect of fertilizers with new nitrification inhibitor DMPP 3-4 dimethylpyrazole phosphate on yield and quality of agricultural and horticultural crops. Biol. Fertil. Soils 34:85-97

[14] Quilchano C. and Maranon T., 2002. Dehydrogenase activity in Mediterranean forest soils. Biol. Fert. Soils, 35, 102-107.

[15] Regina, K., Silvova, J. and P.J. Martikainen. 1998. Mechanism of $\mathrm{N} 2 \mathrm{O}$ and $\mathrm{NO}$ production in the soil profile of drained and forested peat land, as studied with acetylene, nitrapyrin and dimethyl ether. Biol. Fertil. Soils 27: $205-210$

[16] Richter, O., Diekkrueger, B and P. Noertersheuser. 1996. Environmental fate and modelling of pesticides from laboratory to field scale. $\mathrm{VCH}$ Weinheim, New York. pp; 89-93

[17] Serna, M.D, Banuls, J. Quinones, A. Primo-Millo, E and F. Legaz. 2000. Evaluation of 3-4 dimethylpyrazole phosphate as nitrification inhibitor in a citrus-cultivated soils. Biol. Fertil. Soils 32:41-46

[18] Schmitd, K.A. Mc Taggart, I.P and H. Tsurata.1997. Emission of $\mathrm{N} 2 \mathrm{O}$ and $\mathrm{NO}$ associated with nitrigen fertilization in intensive agriculture and potential for mitigation. Soil Use Manag. 13 : 296-304

[19] Spotherfer-Magana, J.; Thalmann, A., and V. Scweikle. 1993. Methode zur Bestimmung der Dehydrogenaseaktivität von Böden unter Einsatz von Iodonitrotetrazoliumchlorid (INT) : Chemische Reduktion in autoklavierten sowie bestrahlten Böden und der Einfluss der Inkubationstemperatur und -zeit. Agribiol. Res, 46:250-268.

[20] Stephenson, G.L., Koper, N., Atkinson, G.F, Solomon.K.R and R.P. Scroggins. 2000. Use of non linear regression techniques for describing 
concentration response-relationships of plants species exposed to contaminated site soils. Environ. Toxicol. Chem., 19:2968-2981

[21] Trenkel, M.E.1997. Improving fertilizer use efficiency controlled released and stabilized fertilizers in agriculture. Internat Fertilizer Industry Association Paris : 151-155

[22] Von Mersi, W and F. Schinner.1991: An improved and accurate method for determining the dehydrogenase activity in soils with iodonitrotetrazolium chloride. Bio. Fertil Soils 11: 216-220.

[23] United States Environmental Protection Agency (USEPA). 1984. Technical guidance manual for performing waste load allocations. Book II: Stream and Rivers. Chapter 3: Toxic Substances: EPA 440/4-84022. Office of Water Washington DC

[24] Von Mersi, W and F. Schinner.1991: An improved and acurate method for determining the dehydrogenase activity in soils with iodonitrotetrazolium chloride. Bio. Fertil Soils 11: 216-220.
[25] Weiske, A., Benckiser, G, Herbert.T, and J.C.G. Ottow. 2001a. Influence of nitrification inhibitor 3-4 dimethylpyrazole phosphate (DMPP) in comparison to dicyandiamide (DCD) on nitrous oxide emission and methane oxidation during 3 years repeated application in field experiments. Biol. Fertil. Soils: 34: 109-117

[26] Weiske, A., Benckiser, G, and J.C.G. Ottow. 2001b. Influence of nitrification inhibitor 3-4 dimethylpyrazole phosphate (DMPP) in comparison to dicyandiamide (DCD) on nitrous oxide (N2O) emission and methane oxidation during 3 years repeated application in field experiments. Nutr. Cycl. Agroecosys. 60: 57-64

[27] Zerulla, W., Barth, T., Dressel, J, Erhardt, K., Horchler von Loqueqhien, K, Pasda, G., Raedle, $M$ and A.H. Weissmeier. 2001. 3-4 dimethylpyrazole phosphate (DMPP) - a new nitrification inhibitor for agriculture and horticulture. An Introduction. Biol. Fertil. Soils: 34: 79-84 